\title{
Simultaneous exploitation of Myrmica vandeli and M. scabrinodis (Hymenoptera: Formicidae) colonies by the endangered myrmecophilous butterfly Maculinea alcon (Lepidoptera: Lycaenidae)
}

\author{
MARCIN SIELEZNIEW ${ }^{1}$ and ANNA M. STANKIEWICZ ${ }^{2}$ \\ ${ }^{1}$ Department of Applied Entomology, SGGW - Warsaw Agriculture University, Nowoursynowska 166, PL-02787 Warszawa, \\ Poland; e-mail: sielezniew@sggw.waw.pl \\ ${ }^{2}$ Laboratory of Social and Myrmecophilous Insects, Museum and Institute of Zoology, Polish Academy of Sciences, Wilcza 64, \\ PL-00679 Warszawa, Poland; e-mail: ams@miiz.waw.pl
}

Key words. Maculinea alcon, host-ant specificity, Myrmica scabrinodis, Myrmica vandeli, Ichneumon, myrmecophily, endangered species, Poland

\begin{abstract}
Host-ant specificity of Maculinea alcon, an endangered obligatory myrmecophilous lycaenid butterfly, was studied at two sites in southern Poland (Świętokrzyskie Mts near Kielce). M. alcon larvae and pupae were found in nests of both Myrmica vandeli and M. scabrinodis, which is the typical host in Poland and Southern Europe. To our knowledge this is the first record of $M$. vandeli as a host of M. alcon. Our results show that M. scabrinodis and M. vandeli are about equally suitable as hosts. We hypothesize that both host ant species are closely related and have similar chemical profiles, and that the M. alcon "scabrinodis-vandeli" populations we studied belong to the M. alcon "scabrinodis" race. More than half of the M. alcon pupae, both from M. vandeli and M. scabrinodis nests, were parasitized by a single wasp species of the genus Ichneumon, which also suggests that the cuticular chemistry of the two ant species is similar.
\end{abstract}

\section{INTRODUCTION}

The Alcon Blue, Maculinea alcon (Denis \& Schiffermüller, 1775), is a representative of the Palaearctic genus Maculinea van Eecke, 1915, which includes about seven obligatory myrmecophilous species (Lepidoptera: Lycaenidae). All of these are initially herbivorous as caterpillars, feeding on specific host plants, but spend their last (fourth) instar in Myrmica Latreille, 1804 ant colonies as social parasites (Thomas, 1995). Because of their extraordinary life history and sensitivity to environmental change, Maculinea butterflies are locally and globally endangered (van Swaay \& Warren 1999; Munguira \& Martin, 1999).

M. alcon inhabits hay meadows, wet heaths and fens. Females lay eggs on Gentiana pneumonanthe L. and some other gentians (Munguira \& Martin, 1999). After the third moult caterpillars leave the plants and fall to the ground where, if lucky, they are encountered by foraging Myrmica ants, which carry them to their nests. Adopted caterpillars mimic ant chemicals (Elmes et al., 2002) and spend 10 months underground being fed like the ant larvae by worker ants. Among the other four European species of the genus Maculinea, only M. rebeli Hirschke, 1904 has the same "cuckoo" habit of parasitism, and the remaining species exploit Myrmica colonies by eating the ant brood (Thomas, 1995).

Butterfly-ant relationships in the genus Maculinea are highly specific. In western Europe M. alcon uses three Myrmica species along a north-south gradient. M. scabrinodis Nylander, 1846 is recorded as the host-ant in France, Spain and southern Netherlands, M. ruginodis Nylander, 1846 in northern Netherlands and Denmark, M. rubra (L., 1758) in Denmark and Sweden (Elmes et al., 1994; Als et al., 2002). However, Eastern European populations of $M$. alcon have hardly been studied so that the distribution and general habitat requirements of $M$. alcon in Eastern Europe is incomplete. During our first survey in Poland we identified M. scabrinodis as the host-ant of $M$. alcon. We suggested that this ant species is the most important host throughout the country but stressed the need for further studies (Sielezniew \& Stankiewicz, 2002). This paper presents additional findings on the ecology and host ant use by $M$. alcon and reports an hitherto unknown host ant.

\section{MATERIAL AND METHODS}

Studies were conducted at two M. alcon sites in southern Poland near Kielce, Świętokrzyskie Mts. The Mt. Otrosz site $\left(50^{\circ} 49^{\prime} \mathrm{N} / 20^{\circ} 41^{\prime} \mathrm{E}\right.$; $350 \mathrm{~m}$ a.s.1.) is a high, isolated, wet meadow surrounded by mixed forest. Less than one hundred G. pneumonanthe plants were found on a small (approx $0.5 \mathrm{ha}$ ) part on this meadow, which was covered mainly with vegetation that can be classified as Molinion. In some places G. pneumonanthe co-occurred also with Calluna vulgaris (L.), while in others it grew among small Pinus sylvestris L. trees or Frangula alnus Mill. bushes. The Jasiów site $\left(51^{\circ} 01^{\prime} \mathrm{N} / 20^{\circ} 39^{\prime} \mathrm{E}\right.$; $350 \mathrm{~m}$ a.s.1.) is generally very similar to the previous site but in area is twelve times bigger (about 6 ha) and consists of three connected meadows. Host plants were present almost everywhere and their distribution was fairly even.

Both sites were investigated just before the $M$. alcon flight period at the beginning of July 2003, with one-day between the surveys at Otrosz and Jasiów. Areas within $1 \mathrm{~m}$ of a few dozen G. pneumonanthe plants on every site were searched for nests of Myrmica ants. Some colonies were easy to find because of welldeveloped solaria, while others were less visible and hidden in tufts of grass or in Sphagnum moss. All nests were very carefully opened and checked for the presence of M. alcon. Larvae and pupae were counted and recorded using a digital video camera, which allowed later measurement of length by comparison with a standard frame. Every pupa was also carefully examined against the light for the possible presence of a parasitoid pupa. After inspection, pupae and larvae were immediately returned to colonies. Some parasitized pupae were taken to the laboratory, 
TABle 1. The number of Myrmica nests within $1 \mathrm{~m}$ of G. pneumonanthe at two M. alcon sites in S-Poland and the number of the nests parasitized by M. alcon.

\begin{tabular}{|c|c|c|c|c|c|c|c|}
\hline Site & $\begin{array}{c}\text { Myrmica ant } \\
\text { species }\end{array}$ & $\begin{array}{c}\text { Sample } \\
\text { size }\end{array}$ & $\begin{array}{c}\% \text { of all } \\
\text { Myrmica nests }\end{array}$ & $\begin{array}{l}\text { Number of nests } \\
\text { with } M . \text { alcon }\end{array}$ & $\begin{array}{l}\text { Total number } \\
\text { of M. alcon }\end{array}$ & $\begin{array}{c}\% \text { of nests } \\
\text { with } M . \text { alcon }\end{array}$ & $\begin{array}{l}\text { Mean number of } M \text {. } \\
\text { alcon per infested nest }\end{array}$ \\
\hline \multirow[t]{2}{*}{ Otrosz } & M. scabrinodis & 19 & 63 & 5 & 19 & 26 & 3.8 \\
\hline & M. vandeli & 11 & 37 & 7 & 24 & 64 & 3.4 \\
\hline \multirow[t]{3}{*}{ Jasiów } & M. scabrinodis & 32 & 62 & 16 & 47 & 50 & 2.9 \\
\hline & M. vandeli & 13 & 25 & 3 & 13 & 23 & 4.3 \\
\hline & M. ruginodis & 7 & 13 & 0 & & & \\
\hline \multirow[t]{3}{*}{ Both sites } & M. scabrinodis & 51 & 62 & 21 & 66 & 41 & 3.1 \\
\hline & M. vandeli & 24 & 29 & 10 & 37 & 42 & 3.7 \\
\hline & M. ruginodis & 7 & 9 & 0 & & & \\
\hline
\end{tabular}

where they were kept until the adult wasps emerged. Samples of 10-20 workers from each nest were collected. Nests were subsequently covered and the surrounding vegetation restored to minimize the impact of our investigation. On both sites the average density of Myrmica nests was estimated, using 20 squares $\left(1 \mathrm{~m}^{2} \mathrm{each}\right)$ positioned at random. Identification of ants was made according to Czechowski et al. (2002) and Radchenko et al. (2003).

The significance of the differences in frequency of $M$. alcon in the nests of different Myrmica species and the proportion of parasitized and unparasitized pupae in the nests of the two ant species were tested using Fisher's exact tests. Differences in numbers of alcon individuals per nest were tested using Kruskal-Wallis tests and differences in pupal size using Wilcoxon tests.

\section{RESULTS}

Three Myrmica ant species were recorded at both sites within foraging range of $G$. pneumonanthe plants (Table 1). A total of 82 Myrmica colonies was sampled. M. scabrinodis (62\%), M. vandeli $(25 \%)$ and M. ruginodis (13\%) were present at Jasiów while only M. scabrinodis (63\%) and M. vandeli Bondroit, 1919 $(37 \%)$ were found at Otrosz. At both sites there were 0.5-2 nests per $1 \mathrm{~m}^{2}$. The only other ants found were Lasius flavus (F., 1782) and Formica cunicularia Latreille, 1798, but they were very rare compared to Myrmica.

M. alcon caterpillars developed successfully in both M. scabrinodis and $M$. vandeli colonies (Table 1), but not $M$. ruginodis colonies. At Jasiów a greater proportion of the nests of $M$. scabrinodis $(50 \%)$ were parasitized, whereas at Otrosz $M$. vandeli $(64 \%)$ was the most common host. Combining the data for both sites, $41 \%$ of the M. scabrinodis colonies had M. alcon and $42 \%$

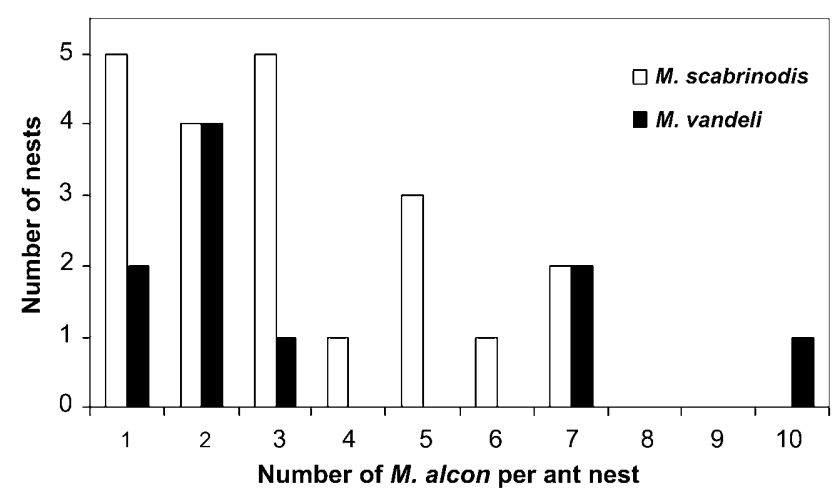

Fig. 1. Frequency distribution of M. alcon caterpillars/pupae in the nests of two Myrmica. of those of M. vandeli. A Fisher's exact test reveal no difference between these percentages $(p=1.0)$.

The general distribution of $M$. alcon individuals in the nests of both Myrmica species is given in Fig. 1. M. alcon in M. vandeli nests were more advanced in development than those in $M$. scabrinodis nests. In 10 nests of M. vandeli there were 36 pupae and 1 prepupa of M. alcon, whereas in 21 M. scabrinodis nests there were: 35 pupae, 12 prepupae and 19 larvae of various size (3.5-13 mm) (Fig. 2). The mean number of caterpillars/pupae per parasitized M. scabrinodis nest was 3.8 at Otrosz (min 1, max 7) and 2.9 at Jasiów $(1,7)$ and for M. vandeli nests it was $3.4(1,7)$ and $4.3(1,10)$, respectively. A Kruskal-Wallis test did not reveal significant differences between sites or ant species $(\mathrm{H}$ $=0.35, \mathrm{p}=0.95$ ). Pupae from M. vandeli nests were significantly bigger than those from $M$. scabrinodis nests ( $\mathrm{W}=798, \mathrm{p}$ $<0.05$ ) (Table 2).

44 of the $71 \mathrm{M}$. alcon pupae $(62 \%)$ were parasitized by ichneumon wasps. The adults reared from pupae were identified as belonging to the genus Ichneumon L., 1758 and closely resembled I. eumerus Wesmael, which is recorded as a parasitoid of $M$. rebeli. The proportion of parasitized pupae was similar in $M$. scabrinodis $(57 \%)$ and M. vandeli $(67 \%)$ nests (Fisher's exact test, $\mathrm{p}=0.47$ ). Pupae parasitized by the Ichneumon were smaller than unparasitized ones but the difference was not significant $(\mathrm{W}=705, \mathrm{p}=0.09)($ Table 2$)$.

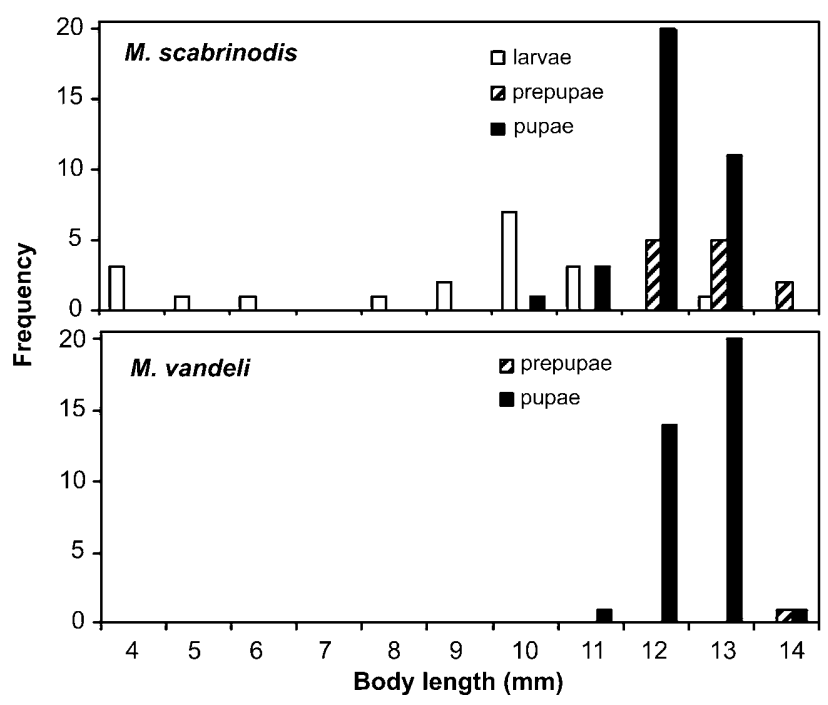

Fig. 2. Frequency distribution of the sizes (in $\mathrm{mm}$ ) of $M$. alcon caterpillars and pupae in the nest of two Myrmica species species. 
TABLE 2. Comparison of the number and the body length of parasitized and unparasitized pupae of M. alcon found in nests of two ant species.

\begin{tabular}{lllllll}
\hline M. alcon pupae & \multicolumn{2}{l}{ parasitized by Ichneumon sp. } & \multicolumn{2}{l}{ unparasitized } & \multicolumn{2}{l}{ Total } \\
\hline Myrmica species & $\mathrm{N}$ & Mean $\pm \mathrm{SD}(\mathrm{mm})$ & $\mathrm{N}$ & Mean $\pm \mathrm{SD}(\mathrm{mm})$ & $\mathrm{N}$ & Mean $\pm \mathrm{SD}(\mathrm{mm})$ \\
\hline M. scabrinodis & 20 & $11.6 \pm 0.6$ & 15 & $11.8 \pm 0.6$ & 35 & $11.7 \pm 0.6^{*}$ \\
M. vandeli & 24 & $12.0 \pm 0.4$ & 12 & $12.2 \pm 0.8$ & 36 & $12.0 \pm 0.5^{*}$ \\
Total & 44 & $11.8 \pm 0.5$ & 27 & $12.0 \pm 0.7$ & 71 & $11.9 \pm 0.6$ \\
\hline
\end{tabular}

* significantly different $(\mathrm{W}=705, \mathrm{p}<0.05)$.

\section{DISCUSSION}

M. vandeli has not previously been recorded as a host of $M$. alcon. This is also the first record of this species being the major host-ant of any Maculinea species. It is recorded as a minor host ant of M. teleius in France (Elmes et al., 1998). The sites are also among the very few localities where two species of $M y r$ mica ants host "cuckoo" Maculinea species with similar effectiveness. Thomas \& Elmes (1998) suggest that the exploitation of ants by $M$. alcon and $M$. rebeli incurs the cost of increased specificity. Only at our sites and some Danish sites is hostspecificity incomplete, and both M. rubra and M. ruginodis used as hosts. According to Als et al. (2002) there are two possible explanations for this: a lower local specificity of M. alcon or the existence of two distinct sub-populations adapted to different hosts. In addition, Elmes et al. (2002) found that hydrocarbon profiles of $M$. rubra and $M$. ruginodis are the most similar among all investigated Myrmica species, and assigned M. alcon individuals reared by them to a single northern race. Biosynthesis of chemicals by M. rebeli, another "cuckoo" Maculinea species, which mimicks the host's brood recognition pheromones, is the first step in the integration of adopted caterpillars within a host-ant colony (Akino et al., 1999).

$M$. vandeli chemicals were not analysed but the simultaneous presence of M. alcon in M. scabrinodis and M. vandeli nests also indicates the close affinity of these two ant species. Both M. vandeli and M. scabrinodis are placed in the scabrinodiscomplex of the genus, with $M$. vandeli being a much rarer species, which usually coexists with $M$. scabrinodis. The occurrence of mixed colonies is also reported from Britain and $M$. vandeli is suspected of being a temporary social parasite of $M$. scabrinodis (Radchenko et al., 2003). Hence we suppose that our scabrinodis-vandeli populations of Alcon Blue belong to the "scabrinodis" race of M. alcon.

The incidence of parasitation of M. alcon pupae by Ichneumon sp. was similar in M. scabrinodis and M. vandeli colonies. If we assume that the behaviour of this parasite is similar to I. eumerus, which locates and parasitizes larvae of M. rebeli in $M$. schencki nests using specific allomones (Thomas et al., 2002), then the $M$. alcon parasite must be adapted to penetrate both M. scabrinodis and M. vandeli colonies. This corroborates the hypothesis that the chemical profiles of both ant species are similar.

M. alcon in $M$. vandeli nests were usually more advanced in development than those in M. scabrinodis colonies. The very small larvae observed in the latter host may suggest a growth polymorphism similar to earlier reports for M. rebeli (Thomas et al., 1998) and M. alcon (Als et al., 2002). We can not exclude the possibility that some larvae in M. scabrinodis nests take two years to develop but we suggest that the size difference may reflect differences in nest size and general suitability. M. vandeli colonies were usually bigger and had conspicuous solaria, while M. scabrinodis colonies were smaller and hidden in turf, especially in Sphagnum moss. Perhaps the more populous colonies and higher temperatures in $M$. vandeli nests accelerated the growth of $M$. alcon larvae. The significantly bigger pupae in $M$. vandeli nests suggest better conditions. Thus the presence of small larvae in M. scabrinodis nests may result from a deficiency of workers rather than from growth polymorphism. Observations of medium sized larvae in M. scabrinodis nests at the end of the flight period (Sielezniew \& Stankiewicz, unpubl.) may confirm this. Also we did not observe "slow developers" in our previous studies. Thus the existence of a growth polymorphism in the scabrinodis race of M. alcon needs confirmation by much larger field samples or by studies using artificial nests.

Two types of Myrmica combinations were recorded at $M$. alcon sites prior to the present study. In meadows situated near forests, M. scabrinodis co-occurs with M. rubra and M. ruginodis in various proportions. This species composition is typical of most European sites (Elmes et al., 1994; Sielezniew \& Stankiewicz, 2002). However in open fen communities in eastern Poland the grasslands are dominated by M. gallienii, with M. scabrinodis present in the drier patches of Molinion vegetation, where G. pneumonanthe occurs (Sielezniew \& Stankiewicz, 2002 and unpubl.). Thus there is a third unique Myrmica community in a different fraction of the M. alcon habitat. A favourable Myrmica species composition, with almost all the colonies of potential hosts, is an ideal site for M. alcon populations and our present sites probably belong to this category. The presence of specialized parasitoids is another indicator of a high quality Maculinea habitat, as they are only able to survive in large stable populations (Munguira \& Martin, 1999). Unidentified ichneumon parasitoids of M. alcon were only previously recorded from Spain and France (Elmes et al., 1994).

Both sites are examples of a very interesting biodiversity complex. M. alcon is recorded in Poland in a few localities mainly in the south and east of the country. A severe decline has occurred in the last decades, as in many other European countries (van Swaay \& Warren, 1999). Mt. Otrosz and especially Jasiów, because of its large area, are important strongholds for M. alcon in Poland. For M. vandeli as a host ant these localities are the only known sites in Poland and are at the north-east edge of the species range. Moreover M. vandeli occurred at high densities at both sites, and in proportions relative to M. scabrinodis comparable only to localities in the French Alps (Elmes \& Thomas, 1985). We hope that the presence of this butterfly species, as well as its parasitoid and a rare species of ant will be a strong argument for the conservation of the whole habitat.

ACKNOWLEDGEMENTS. We are very grateful to J. Buszko for access to unpublished data on $M$. alcon distribution in Poland and to M. Gwardian, for the precise site location. We also thank three anonymous referees for valuable and constructive comments on the manuscript. This work was supported by KBN - The State Committee for Scientific Research (grant no. 3-PO4G-026-24). 


\section{REFERENCES}

Akino T., Knapp J.J., Thomas J.A. \& Elmes G.W. 1999: Chemical mimicry and host specificity in the butterfly Maculinea rebeli, a social parasite of Myrmica ant colonies. Proc. R. Soc. Lond. (B) 266: 1419-1426.

Als T.D., Nash D.R. \& Boomsma J.J. 2002: Geographical variation in host-ant specificity of the parasitic butterfly Maculinea alcon in Denmark. Ecol. Entomol. 27: 403-414.

Czechowski W., Radchenko A. \& Czechowska W. 2002: The Ants (Hymenoptera, Formicidae) of Poland. Museum and Institute of Zoology PAS, Warsaw, $200+1$ pp.

Elmes G.W. \& Thomas J.A. 1985: Morphometrics as a tool in identification: a case study of a Myrmica from France (Hymenoptera, Formicidae). Act. Coll. Insectes Soc. 2: 97-108.

Elmes G.W., Thomas J.A., Hammarstedt O., Munguira M.L., Martin J. \& van der Made J.G. 1994: Differences in hostants specificity between Spanish, Dutch and Swedish populations of the endangered butterfly Maculinea alcon (Denis et Schiff.) (Lepidoptera). Memorab. Zool. 48: 55-68.

Elmes G.W., Thomas J.A., Wardlaw J.C., Hochberg M.E., Clarke R.T. \& Simcox D.J. 1998: The ecology of Myrmica ants in relation to the conservation of Maculinea butterflies. $J$. Insect Cons. 2: 67-78.

Elmes G.W., Akino T., Thomas J.A., Clarke R.T. \& Knapp J.J. 2002: Interspecific differences in cuticular hydrocarbon profiles of Myrmica ants are sufficiently consistent to explain host specificity by Maculinea (large blue) butterflies. Oecologia 130: 525-535.

Munguira M.L. \& Martin J. 1999: Action Plan for the Maculinea Butterflies in Europe. Nature and Environment, No. 97. Council of Europe Publishing, Strasbourg, 64 pp.
Radchenko A., Elmes G.W., Czechowska W., Stankiewicz A., Czechowski W. \& Sielezniew M. 2003: First records of Myrmica vandeli Bondroit and M. tulinae Elmes Radchenko et Aktaç (Hymenoptera: Formicidae) for Poland, with a key for the scabrinodis- and sabuleti-complexes. Fragm. Faun. 46: $47-57$.

Sielezniew M. \& Stankiewicz A. 2002: First data on host-ant specificity of parasitic butterfly Maculinea alcon (Den. \& Schiff.) (Lepidoptera: Lycaenidae) in Poland and eastern Europe. Fragm. Faun. 45: 123-130.

Thomas J.A. \& Elmes G.W. 1998: Higher productivity at the cost of increased host-specificity when Maculinea butterfly larvae exploit ant colonies through trophallaxis rather than by predation. Ecol. Entomol. 23: 457-464.

Thomas J.A. 1995: The ecology and conservation of Maculinea arion and other European species of large blue butterfly. In Pullin A.S. (ed.): Ecology and Conservation of Butterflies. Chapman \& Hall, London. pp. 180-197.

Thomas J.A., Elmes G.W. \& Wardlaw J.C. 1998: Polymorphic growth in larvae of the butterfly Maculinea rebeli, a social parasite of Myrmica ant colonies. Proc. R. Soc. Lond. (B) 265: 1895-1901.

Thomas J.A., Knapp J.J., Akino T., Gerty S., Wakamura S., Simcox D.J., Wardlaw J.C. \& Elmes G.W. 2002: Parasitoid secretions provoke ant warfare. Nature 417: 505-506.

VAn SwaAy C.A.M. \& WARren M. 1999: Red Data Book of European Butterflies (Rhopalocera). Nature and Environment, No. 99. Council of Europe Publishing, Strasbourg, 260 pp.

Received January 29, 2004; revised May 24, 2004; accepted July 8, 2004 